\title{
Induction of fibronectin gene expression by inhibitors of protein phosphatase yype 2B in normal and transformed fibroblasts
}

\author{
Jung-Hwa Rhew ${ }^{1}$, Young-Ah Shin ${ }^{1}$, Byung-Heon \\ Lee $^{2}$, Rang-Woon Park ${ }^{1}$ and In-San Kim ${ }^{1,3}$ \\ 1 Department of Biochemistry, School of Medicine, Kyungpook National University, \\ 101 Dongin-Dong, Taegu, 700-422, Korea \\ 2 Department of Biochemistry, School of Medicine, Dongguk University, 707 \\ Sukjang-dong, Kyungju, 780-714, Korea \\ 3 Corresponding author: Tel, +82-53-420-6934; Fax, +82-53-422-1466; E-mail, \\ iskim@bh.kyungpook.ac.kr \\ Accepted 15 April 1999
}

Abbreviations: FN, fibronectin; PKC, protein kinase C; PP2B, protein phosphatase type $2 B$; MEM, minimal essential medium; $B S A$, bovine serum albumin; $F B S$, fetal bovine serum; PMA, phorbol myristate acetate; PP1, protein phosphatase type 1; PP2A, protein phosphatase type $2 \mathrm{~A}$; TGF- $\beta$, transforming growth factor- $\beta$
Keywords: ascomycin, cyclosporin A, fibroblasts, fibronectin, protein phosphatase $2 \mathrm{~B}$ Introduction

Fibronectin (FN) is a large, extracellular matrix (ECM) glycoprotein that functions as both plasma and ECM protein. It is composed of two subunits of about 230 and $250 \mathrm{kDa}$ that are cross-linked by disulfide bonds. FN serves as an attachment factor for cell-matrix and cell-cell interactions in various biological processes such as adhesion, differentiation, and migration (Rouslahti, 1981, 1988; Hynes, 1990). Many different FN polypeptides are generated from a single gene by alternative splicing (Borsi et al., 1987; Norton and Hynes, 1987; Schwarzbauer et al., 1987; Zardi et al.,1987). FN has several domains known to bind a variety of matrix proteins such as type I collagen and also it has a specific amino acid sequence RGD that is recognized by a transmembrane receptor, integrin expressed on many cells (Hynes, 1987; Rouslahti and Pierschbacher, 1987). A variety of growth factors and cytokines are being evaluated as modulators of $\mathrm{FN}$ gene expression in many different cell types (Nernath et al.,1980; Senger et al., 1983; Allen-Hoffmann and Mosher, 1987; Almendral et al., 1988; Blatti et al., 1988; Bowlus et al., 1991; Dean et al.,1988, Dean et al., 1989). As we previously reported (Lee et al., 1996; Lee et al., 1997; Lee et al., 1998), two intracellular signal pathways mediated by cAMP and protein kinase $C$ (PKC) are involved in the regulation of FN gene expression. These findings led us to investigate whether protein phosphatase-dependent pathways may also be responsible for $\mathrm{FN}$ gene expression. Here, we reported that ascomycin and cyclosporin $A$, inhibitors of serine/threonine protein phosphatase type 2B (PP2B), stimulated FN gene expression in WI-38 human lung fibroblasts and its SV-40 transformed derivative, WI38VA13, but not in MC3T3-E1 osteoblasts.

\section{Materials and Methods}

\section{Materials}

Minimal essential medium (MEM), $\alpha-M E M$, and fetal bovine serum (FBS) were purchased from Gibco/BRL (Gaithersburg, MD, U.S.A.). Bovine serum albumin (BSA), nonessential amino acids, pyruvic acid, phorbol-12myristate-13-acetate (PMA), goat anti-human FN antibody, and cycloheximide (CHX) were from Sigma (St. Louis, $M O$, U.S.A.). Cyclosporin A and ascomycin were from BIOMOL (Plymouth Meeting, PA, U.S.A.). Protein ASepharose was from Pharmacia (Milwaukee, WI, U.S.A.). 
Culture plastic wares were from Costar (Cambridge, MA, U.S.A.). Nitrocellulose membrane, $\left[{ }^{35}\right.$ S]methionine, $\left[{ }^{32} \mathrm{P}\right] \mathrm{dCTP}(3,000 \mathrm{Ci} / \mathrm{mmol})$ and random primed DNA labeling kit were from Amersham (Arlington, IL, U.S.A.). The ExpressHyb ${ }^{\mathrm{TM}}$ hybridization solution was from Clontech (Palo alto, CA, U.S.A.).

\section{Cell cultures}

A normal human lung fibroblast cell line WI-38, an SV40 virus-transformed derivative of WI-38, WI-38VA13, and a mouse calvarial osteoblastic cell line MC3T3-E1 were obtained from the American Type Culture Collection (Rockville, MD, U.S.A.). WI-38 and WI-38VA13 were cultured in MEM supplemented with10\% FBS. MC3T3E1 was cultured in a-MEM supplemented with $10 \%$ FBS. Each medium used in this study was supplemented with $100 \mathrm{U} / \mathrm{ml}$ of penicillin, $100 \mathrm{mg} / \mathrm{ml}$ of streptomycin, and $0.1 \%$ nonessential amino acids (only for WI-38VA13), and $1 \mathrm{mM}$ pyruvic acid (only for WI-38VA13). Cells were incubated in a humidified atmosphere of $5 \% \mathrm{CO}_{2}$ at $37^{\circ} \mathrm{C}$.

\section{Radioactive labeling and immunoprecipitation}

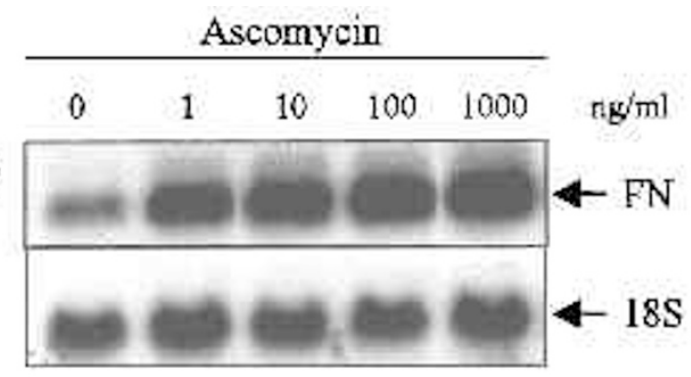

(B)

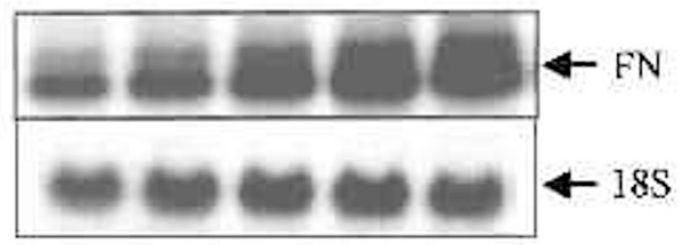

(C)

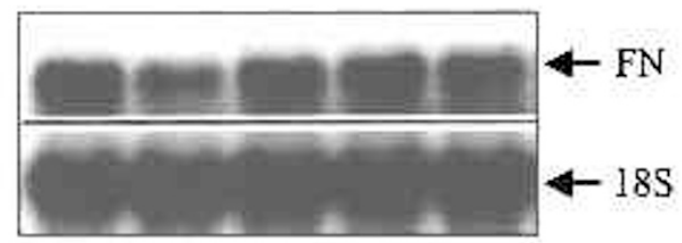

Figure 1. Effect of ascomycin on fibronectin (FN) mRNA levels in WI-38. (A), WI-38VA13 (B) and MC3T3-E1 (C). Confluent cells were treated with the indicated concentrations of ascomycin for $24 \mathrm{~h}$. Total RNA extraction and Northern blot analysis were performed as described in Materials and Methods. 18S, 18S ribosomal RNA.

\section{of FN}

Confluent cells in 35-mm culture dishes were incubated with serum free media supplemented with $1 \%$ BSA and the indicated agents and then labeled for two hours with methionine-free MEM containing $30 \mu \mathrm{Ci} / \mathrm{ml}$ of [ ${ }^{35} \mathrm{~S}$ ] methionine. Radiolabeled FN was immunoprecipitated as described previously (Lee et. al., 1996). Excess (3 $\mathrm{mg}$ ) of goat anti-human FN antibody was added to the combined samples of medium and cell layer extracts containing the same amounts of radioactive protein and then incubated at $4^{\circ} \mathrm{C}$ for $1 \sim 2 \mathrm{~h}$. The immune complexes were recovered by addition of $30 \mathrm{ml}$ of protein ASepharose beads, and incubated with shaking for an additional1 hour. The adsorbed proteins on Sepharose beads were dissolved in a $30 \mathrm{ml}$ of electrophoresis sample buffer heated at $100^{\circ} \mathrm{C}$ for $4 \mathrm{~min}$. Samples were analyzed by SDS-PAGE using a $6 \% \mathrm{gel}$, and subjected to fluorography.

\section{Northern blot hybridizations}

Total cellular RNA was isolated with acid guanidinium thiocyanate-phenol-chloroform as described previously (Chomczynski and Sacchi,1987). Ten $\mu \mathrm{g}$ of total cellular RNA per sample were fractionated by electrophoresis on a $0.8 \%$ agarose gel containing $2.2 \mathrm{M}$ formaldehyde, trans-

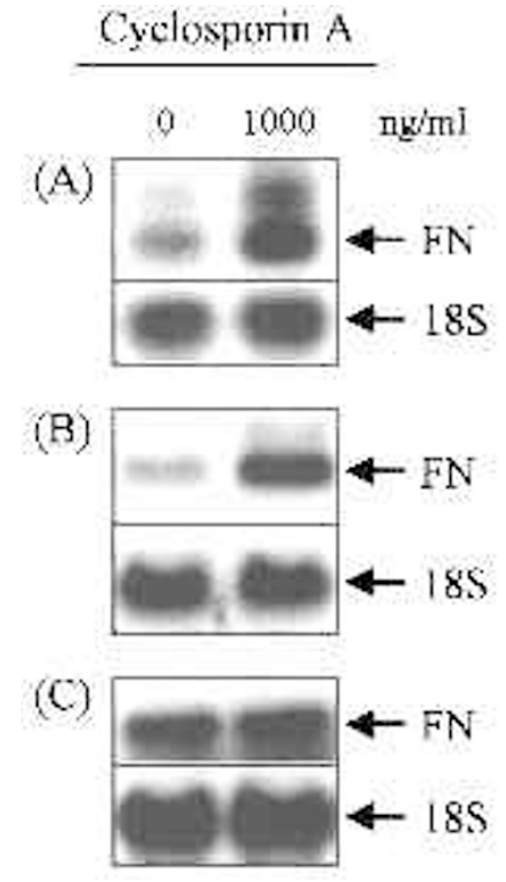

Figure 2. Effect of cyclosporin A on fibronectin (FN) mRNA levels in WI-38. (A), WI-38VA13 (B), and MC3T3-E1 (C). Confluent cells were treated with the indicated concentrations of cyclosporin A for $24 \mathrm{~h} .18 \mathrm{~S}, 18 \mathrm{~S}$ ribosomal RNA. 
(A)

\begin{tabular}{|c|c|c|c|c|c|c|c|c|c|}
\hline $3 C$ & 3h & $6 \mathrm{C}$ & $6 \mathrm{~h}$ & $12 \mathrm{C}$ & $12 \mathrm{~h}$ & $24 \mathrm{C}$ & $24 \mathrm{~h}$ & $48 C$ & $48 \mathrm{~h}$ \\
\hline 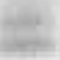 & $=$ & & 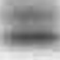 & 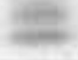 & & anes & & & $a$ \\
\hline
\end{tabular}

(B)

Ascomycin

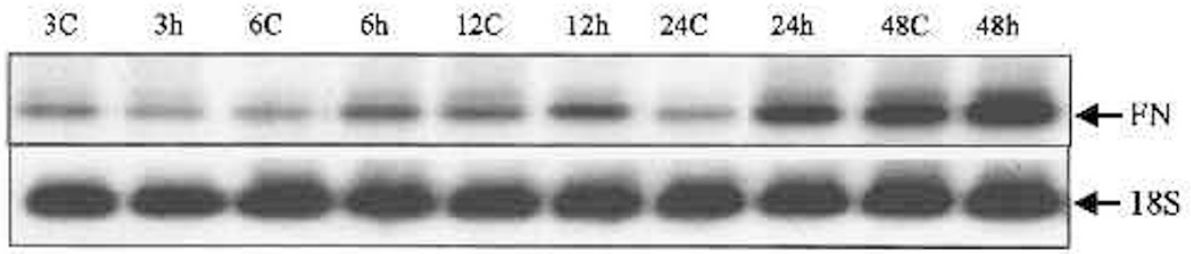

Figure 3. Time kinetics of fibronectin (FN) mRNA levels by cyclosporin $A(A)$ and ascomycin (B) in Wl-38. Cells were treated with cyclosporin $A(1,000 \mathrm{ng} / \mathrm{ml})$ or ascomycin $(1,000 \mathrm{ng} / \mathrm{ml})$ for the indicated periods of time. $18 \mathrm{~S}, 18 \mathrm{~S}$ ribosomal RNA; C, control.

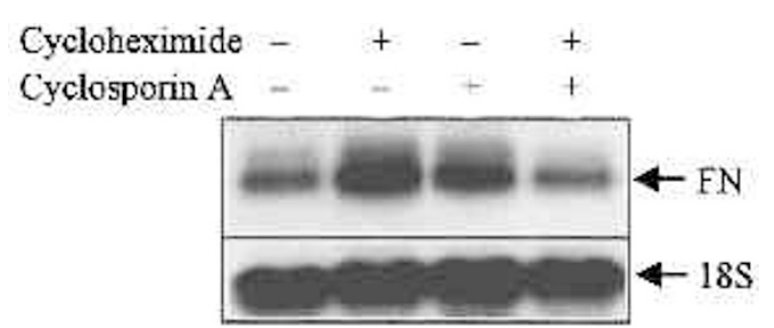

Figure 4. Effect of cycloheximide on the cyclosporin A-induced fibronectin (FN) mRNA levels. Confluent WI-38 cells were pre-treated with cycloheximide $(10 \mathrm{mg} / \mathrm{ml})$ before treatment of cyclosporin A (1,000 ng/ml) for $24 \mathrm{~h} .18 \mathrm{~S}, 18 \mathrm{~S}$ ribosomal RNA.

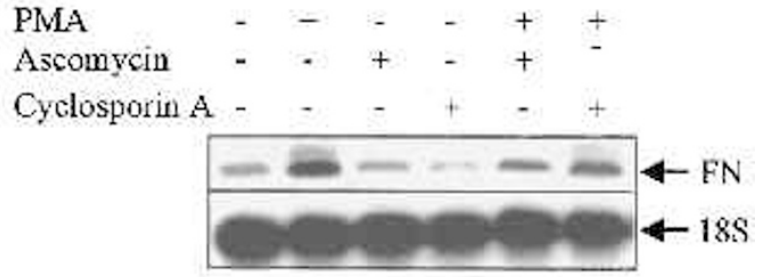

Figure 5. Effect of phorbol myristate acetate (PMA) alone or in combination with ascomycin or cyclosporin A on fibronectin (FN) mRNA levels in WI-38. Cells were treated with PMA $(10 \mathrm{ng} / \mathrm{ml})$ in combination with cyclosporin $\mathrm{A}(1,000 \mathrm{ng} / \mathrm{ml})$ or ascomycin $(1,000 \mathrm{ng} / \mathrm{ml})$ for $24 \mathrm{~h}$. 18S, $18 \mathrm{~S}$ ribosomal RNA. ferred to a nylon membrane followed by hybridization and subsequent washing as described by Sambrook et al. (1989). A cDNA probe was labeled with [ $\left.{ }^{32} \mathrm{P}\right] \mathrm{dCTP}$ using a random primed DNA labeling kit. The membrane was exposed to a X-ray film at $-70^{\circ} \mathrm{C}$. The cDNA probes used for hybridization were $\mathrm{FH} 1$, human FN CDNA (Kornblihtt, et. al., 1983) and 18S ribosomal RNA cDNA.

\section{Results and Discussion}

In order to determine the effect of a PP2B inhibitor ascomycin on FN mRNA levels in normal and transformed lung fibroblasts, WI-38 and WI-38VA13, respectively and in MC3T3-E1osteoblasts, cells were exposed to ascomycin ranging from 1 to $1,000 \mathrm{ng} / \mathrm{ml}$ for $24 \mathrm{~h}$ and the steady state levels of FN mRNA were determined by Northern blot hybridization. Ascomycin increased FN mRNA levels in WI-38 and WI-38VA13 cells in a dosedependent manner but not in MC3T3-E1 cells (Figure 1). Cyclosporin A, another inhibitor of PP2B, also increased
FN mRNA levels in WI-38 and WI-38VA13 cells but not in MC3T3-E1 cells (Figure 2). A cDNA for $18 \mathrm{~S}$ ribosomal RNA was used to correct the amount of RNA loaded. We also tested okadaic acid and calyculin A, protein phosphatase type 1 (PP1) and protein phosphatase type 2A (PP2A) inhibitors, resulting in marked stimulation of $F N$ gene expression in MC3T3-E1 cells but not in WI-38 and WI-38VA13 cells (data not shown). These results suggest that the regulation of FN gene expression by protein dephosphorylation is different depending on cell types.

To study the time kinetics of mRNA levels, confluent WI-38 cells were treated with $1,000 \mathrm{ng} / \mathrm{ml}$ of cyclosporin A or $1,000 \mathrm{ng} / \mathrm{ml}$ of ascomycin for the indicated periods of time. Post-treatment levels of FN mRNA began to increase from $6 \mathrm{~h}$ up to $48 \mathrm{~h}$ with both agents. (Figure 3). A protein synthesis inhibitor $\mathrm{CHX}$ was added $30 \mathrm{~min}$ before the addition of cyclosporin $\mathrm{A}$. While $\mathrm{CHX}$ itself increased levels of FN mRNA in WI-38 cells, it blocked the cyclosporin A-induced increase of FN mRNA levels 
(Figure 4), suggesting that a new protein synthesis is required for the induction of $\mathrm{FN}$ gene expression by cyclosporin A.

We have reported that PMA increases $F N$ synthesis and gene expression in WI-38 and WI-38VA13 cells through the PKC-dependent pathway (Lee et al., 1996). We have also found that PMA induces FN gene expression in MC3T3-E1 (data not shown). To investigate whether ascomycin and cyclosporin A effect the PMA-induced FN synthesis or vice versa, WI- 38 cells were treated with $10 \mathrm{ng} / \mathrm{ml}$ of PMA alone or in combination with ascomycin or cyclosporin A. A lower concentration $(1 \mathrm{ng} / \mathrm{ml})$ of ascomycin and cyclosporin A which merely stimulated FN gene expression was used. FN gene expression was stimulated by PMA alone but not by either ascomycin or cyclosporin A alone at a given concentration (Figure 5). In addition, the PMA -induced stimulation was not enhanced by the combined treatment of PMA with either ascomycin or cyclosporin A (Figure 5). These results suggest that the mechanism of PMA and ascomycin/cyclosporin A in the regulation of $\mathrm{FN}$ gene expression may share a common downstream pathway.

This is the first report to show that PP2B is involved in the regulation of $\mathrm{FN}$ gene expression. Cyclosporin $\mathrm{A}$ and ascomycin are well-known immunosuppressants and their inhibitory action on calcineurin, a $\mathrm{Ca}^{2+} /$ calmodulindependent PP2B, is mediated by making complex to their intracellular receptors, cyclophilin and FK506 binding protein, respectively (Fruman et al., 1994). Cyclosporin $A$ has been widely used for the prevention of a graft rejection (Liu et al., 1991). However, one of the major concerns is its potential nephrotoxicity causing interstitial fibrosis (Myers, 1986). Therefore, its effects on the transcription and synthesis of extracellular matrix proteins such as type I and IV collagen have been studied. Wolf et al. (1990) reported that cyclosporin A stimulated collagen synthesis and gene expression in kidney fibroblasts and tubular cells. Frizell et al. (1994) reported that another PP2B inhibitor FK506 also increased the expression of extracellular matrix genes. Here we reported that $F N$, one of the important extracellular matrix proteins, are also upregulated by cyclosporin $A$ and ascomycin suggesting that the increased synthesis of FN by them may contribute to the tissue fibrosis which is one of major side effects of these immunosuppressant drugs. Although the precise mechanism of the action of cyclosporin $A$ and ascomycin on FN gene expression are uncertain, the results of this study provide an insight for understanding the regulatory mechanisms of $\mathrm{FN}$ gene expression in response to various extracellular stimuli. Indeed, a recent study provided evidences that cyclosproin $A$ induced transforming growth factor- $\beta$ (TGF- $\beta$ ) production which in turn enhanced tumor growth and the number of metastasis (Hojo et al., 1999). Our results that cyclosporin A requires a new protein synthesis to induce FN synthesis suggest that the effect of cyclosporin A may act indirectly through TGF- $\beta$ production.
In addition, our results showed that the regulation of FN expression by protein phosphatase seems to be celltype specific since PP2B inhibitors such as cyclosporin $A$ and ascomycin increased $F N$ expression in fibroblasts but not in osteoblasts.

\section{Acknowledgement}

This work was supported by a grant of Kyungpook University Hospital and a grant BSRI 98-4403 from the Korean Research Foundation of the Ministry of Education provided in the program year of 1998.

\section{References}

Allen-Hoffmann, B. L. and Mosher, D. F. (1987) Matrix assembly sites for exogenous fibronectin are decreased on human fibroblasts after treatment with agents which increase intracellular cAMP.J. Biol. Chem. 262: 14361-14365

Almendral, J. M., Sommer, D., Macdornald-Bravo, H., Burckhardt, J., Perera, J. and Bravo, R. (1988) Complexity of the early genetic response to growth factors in mouse fibroblasts. Mol. Cell Biol. 8: 2140-2148

Bernath, V. A., Muro, A. F., Vitullo, A. D., Bley, M. A., Baranao, J. L. and Kornblihtt, A. R. (1990) Cyclic AMP inhibits fibronectin gene expression in a newly developed granulosa cell line by a mechanism that suppresses cAMP-responsive element-dependent transcriptional activation. J. Biol. Chem. 264: 9069-9076

Blatti, S. P., Foster, D. N., Ranganathan, G., Moses, H. L. and Getz, M. J. (1988) Induction of fibronectin gene transcription and mRNA is a primary response to growth-factor stimulation of AKR-2B cells. Proc. Natt. Acad. Sci. USA 85: 1119-1123

Borsi, L., Carnemolla, B., Castellani, P., Rosellini, C., Vecchio, D., Allemanni, G., Chang, S. E., Taylor-Paradimitriou, J., Pande, H. and Zaldi, L. (1987) Monoclonal antibodies in the analysis of fibronectin isoforms generated by alternative splicing of mRNA precursors in normal and transformed human cells. J. Cell. Biol. 104: 595-600

Bowlus, C. L., McQuillan, J. J. and Dean, D. C. (1991) Characterization of three different elements in the 5'-flanking region of the fibronectin gene which mediate a transcriptional response to cAMP, J. Biol. Chem. 266: 1122-1127

Chomczynski, P. and Sacchi, N. (1987) Single-step method of RNA isola-tion by acid guanidium thiocyanate-phenol-chloroform extraction. Anal. Biochem. 162: 156-159

Dean, D. C., Blakeley, M. S., Newby, R. F., Ghazal, P., Hennighausen, L. and Bourgeois, S. (1989) Forskolin inducibility and tissue-specific expression of the fibronectin promoter. Mol. Cell Biol. 9: 1498-1506

Dean, D. C., Newby, R. F. and Bourgeois, S. (1988) Regulation of fibronectin biosynthesis by dexamethasone, transforming growth factor, and cAMP in human cell lines. J. Cell. Biol. 106: 2159-2170

Frizell, E., Abraham, A., Doolittle, M., Bashey, R., Kresina, T., Thiel, D. V. and Zern M. A. (1994) FK506 enhances fibrogenesis in vitro and in vivo models of liver fibrosis in rats. Gastroenterology 107: 492-498

Fruman, D. A., Burakoff, S. J. and Bierer, B. E. (1994) Immunophilins in protein folding and immunosuppression. FASEB J. 8: 391-400

Hojo, M., Morimoto, T., Maluccio, M., Asano, T., Morimoto, K., Lagman, M., Shimbo, T., and Suthanthiran, M. (1999) Cyclosporin induces cancer progression by a cell-autonomous mechanism. Nature 397: 530-534

Lee, B.-H., Park, R.-W., Choi, J.-Y., Ryoo, H.-M., Sohn, K.-Y. and Kim I.-S. (1996) Stimulation of fibronectin synthesis through the protein kinase $C$ signaling pathway in normal and transformed human lung fibroblasts. Biochem.Mol. Biol. Int. 39: 895-904

Lee, B.-H., Park, R.-W., Sohn, K.-Y. and Kim, I.-S. (1997) Antagonistic regulation of protein kinase $\mathrm{C}$-induced stimulation of fibronectin synthesis by cyclic AMP in human lung fibroblasts. Biochem. Mol. Biol. Int. 43: 383-390 
Lee, B.-H., Park, R.-W. and Kim, I.-S. (1998) Regulation of fibronectin gene expression by cyclic AMP and phorbol myristate acetate in HT-1080 human fibrosarcoma cells. Exp. Mol. Med. 30: 240-245

Liu, J., Farmer, J. D. Jr., Lane, W. S., Friedman, J., Weisman, I. and Schreiber, S. L. (1991) Calcineurin is a common target of cyclosphillin-cyclosporin A and FKBP-FK506 complexes. Cell 66: 807-815

Myers, B. D. (1996) Cyclosporin nephrotoxicity. Kidney Int. 30: 964-974

Norton, P. A. and Hynes, R. O. (1987) Alternative splicing of chicken fibronectin in embryos and in normal and transformed cells. Mol. Cell Biol.7: 4297-4307

Ruoslahti, E. (1988) Fibronectin and its receptors. Ann. Rev. Biochem. 57: 375-413

Ruoslahti, E., Engvall, E. and Hayman, E. G. (1981) Fibronectin: current concepts of its structure and function. Collagen Res. 1: 95-128

Sambrook, J., Fritsch, E. F. and Maniatis, T. (1989) Molecular cloning: A laboratory manual. 2nd ed., pp7.1-7.52, Cold Spring Harbor Laboratory Press, New York

Schwarzbauer, J. E., Patel, R. S., Fonda, D. and Hynes., R. O. (1987) Multiple sites of alternative splicing of the rat fibronectin gene transcript. EMBO J. 6: 2573-2580
Senger, D. R., Destree, A. T. and Hynes, R. O. (1983) Complex regulation of fibronectin synthesis by cells in culture. Am. J. Physiol. 245: C144-C150

Wolf, G., Killen, P. D. and Neilson, E. G. (1990) Cyclosporin A stimulates transcription and procollagen secretion in tubulointerstitial fibroblasts and proximal tubular cells. J. Am. Soc. Nephrol. 1: 918-922

Zardi, L., Camemolla, B., Siri, A., Petersen, T. E., Paolella, G., Sebastio, G. and Baralle, F. E. (1987) Transformed human cells produce a new fibronectin isoform by preferential alternative splicing of a previously un-observed exon. EMBO J. 6: 2337-2342 